\title{
PENGARUH LAYANAN BIMBINGAN KELOMPOK TERHADAP PENINGKATAN KEDISIPLINAN SISWA
}

\author{
Oleh: \\ Risma $^{1)}$, Waode Suarni ${ }^{2)}$, Alber Tigor Arifyanto ${ }^{3)}$ \\ 1) 2) 3) Jurusan Bimbingan dan Konseling \\ Fakultas Keguruan dan Ilmu Pendidikan, Universitas Halu Oleo \\ Email: Rismaumha16@gmail.com
}

\begin{abstract}
ABSTRAK
Penelitian ini bertujuan untuk mengetahui adanya pengaruh layanan bimbingan kelompok terhadap peningkatan kedisiplinan siswa. Jenis penelitian ini adalah penelitian pra eksperimen dengan desain one group pre test and post test. Subjek penelitian ini berjumlah 8 siswa. Data dikumpulkan dengan menggunakan angket kedisiplinan siswa. Hasil analisis deskriptif menunjukkan bahwa kedisiplinan siswa sebelum diberikan perlakuan berupa layanan bimbingan kelompok berada pada kategori rendah. Sedangkan setelah diberikan perlakuan mengalami peningkatan $16,47 \%$. Berdasarkan hasil analisis statistik inferensial menggunakan uji Wilcoxon signed rank pada taraf signifikan $\alpha=0,05$ diperoleh $\mathrm{P}_{\text {value }}=0,027$. $\mathrm{P}_{\text {value }}<\alpha(0,027<0,05)$ dengan demikian layanan bimbingan kelompok berpengaruh terhadap peningkatan kedisiplinan siswa. Dari hasil tersebut, disimpulkan bahwa bimbingan kelompok berpengaruh terhadap peningkatan kedisiplinan siswa SMP Kesehatan Mandonga Kendari.
\end{abstract}

Kata Kunci: Kedisiplinan, Bimbingan Kelompok

\section{THE INFLUENCE OF GROUP GUIDANCE SERVICES ON INCREASING STUDENTS' DISCIPLINE}

\begin{abstract}
This study aims to determine the influence of group guidance services to increase student discipline. Type of this research is preexperimental research with one group design pre test and post test. The subjects of this study were 8 students. The data was collected using student discipline questionnaires. The results of the descriptive analysis showed that the discipline of students before being given treatment in the form of group guidance services was in the low category. While after being given treatment, it increased $16.47 \%$. Based on the results of inferential statistical analysis using the Wilcoxon signed rank test at a significant level $\alpha=0,05$ obtained $p_{\text {value }}=0,027 p_{\text {value }}<\alpha(0,027<0,05)$ thus group guidence services are influential to increase student discipline. From these results it was concluded that the guidance of the group was influential in increasing the discipline of SMP Kesehatan Mandonga Kendari.
\end{abstract}

Keywords: Discipline, Group Guidance 


\section{Pendahuluan}

Dalam lingkup sekolah, kedisiplinan merupakan hal pokok yang harus diperhatikan. Kedisiplinan dalam proses pendidikan sangat diperlukan karena bukan hanya untuk menjaga kondisi suasana belajar dan mengajar yang kondusif tetapi membentuk karakter dan jiwa yang kuat bagi peserta didik.

Pelaksanaan disiplin harus dimulai dari dalam diri siswa. Karena tanpa dari diri siswa itu sendiri, maka apapun usaha yang dilakukan oleh orang di sekitarnya hanya akan sia-sia. Setelah itu baru dilakukan upaya-upaya dari luar diri siswa dan lingkunganya. Dengan demikian, kedisiplinan di sekolah sangat diperlukan, karena kedisiplian merupakan tolak ukur untuk menilai seseorang dalam menaati aturan yang berlaku. Dalam lingkup sekolah, aturan dan tata tertib yang berlaku merupakan cerminan akan kedisiplinan semua siswa sekolah yang ada di dalamya dan yang paling penting adalah potret dari kedisiplinan peserta didiknya. Adapun tolak ukur tata tertib di Sekolah Menengah Pertama (SMP) yaitu datang tepat waktu, berpakaian seragam lengkap, melaksanakan tugas piket, tidak merusak fasilitas sekolah, masuk kelas tepat waktu dan menjaga nama baik sekolah.

Disiplin merupakan ketaatan dan ketepatan pada suatu aturan yang dilakukan secara sadar tanpa adanya dorongan atau paksaan dari pihak lain dan terbentuk melalui proses dari serangkaian perilaku yang menunjukkan nilai-nilai ketaatan, kepatuhan, kesetiaan, keteraturan atau ketertiban. Rachman (1999) mengemukakan bahwa tujuan disiplin sekolah yakni: 1) memberi dukungan bagi terciptanya perilaku yang tidak menyimpang, 2) mendorong siswa melakukan yang baik dan benar, 3) membantu siswa memahami dan menyesuaikan diri dengan tuntutan lingkungan dan menjauhi hal-hal yang dilarang oleh sekolah, siswa belajar hidup dengan kebiasaan-kebiasaan dari yang baik dan bermanfaat baginya serta lingkungannya.

Namun kenyataan di Sekolah Menengah Pertama (SMP) Kesehatan Mandonga Kendari menunjukkan bahwa kedisiplinan peserta didik saat ini masih cenderung rendah. Masih terjadi pelanggaran tata tertib yang ada, baik tata tertib yang menyangkut pelajaran maupun tata tertib yang menyangkut perilaku di lingkungan sekolah. Misalnya masih ada kasus tentang membolos saat jam pelajaran sedang berlangsung, tidak mengikuti upacara, datang terlambat, tidak mengerjakan setiap tugas dari guru akibatnya nilai rapornya sangat buruk, tidak masuk sekolah tanpa keterangan, orang tua siswa juga sangat sering dipanggil ke sekolah dan juga kasus-kasus lain yang berhubungan dengan kedisiplinan siswa. Sebagai suatu instansi yang berkecimpung dalam dunia pendidikan sekolah berkewajiban untuk menanamkan kedisiplinan melalui peraturan dan tata tertib yang berlaku di dalamnya.

Berdasarkan hasil wawancara dengan guru Bimbingan dan Konseling (BK) di Sekolah Menengah Pertama (SMP) Kesehatan Mandonga, masih ditemukan tingkat kedisiplinan siswa yang cenderung rendah, hal itu dapat dilihat dari perilaku siswa-siswi yaitu datang terlambat, dengan berbagai alasan seperti: rumah jauh, karena menunggu angkot, kerapian, keluar masuk ruangan pada saat proses pembelajaran berlangsung, sering alpa, pulang lebih awal sebelum jam pelajaran selesai, etika dalam berkomunikasi antara sesama siswa dan guru sama. Hal yang serupa diungkapkan oleh guru wali kelas yang menyatakan bahwa ada beberapa siswa yang sering terlambat masuk dalam kelas saat proses pembelajaran berlangsung, tidak fokus mengikuti pelajaran, ribut, piket kelas tidak dilaksanakan oleh siswa yang bersangkutan, atribut tidak lengkap, bolos, membuang sampah tidak pada tempatnya dan main handphone (HP) saat jam pelajaran berlangsung.

Salah satu upaya sekolah melalui petugas piket di Sekolah Menengah Pertama (SMP) Kesehatan Mandonga Kendari dalam menangani permasalahan yang dihadapi oleh peserta didik dalam perilaku disiplin adalah berupa teguran, seperti memberi peringatan, menasehati, memberi sanksi yaitu tidak diperkenankan mengikuti pelajaran sampai pergantian jam, memberi informasi yang berkaitan dengan aturan-aturan tata tertib yang sudah diterapkan. Berbagai cara sudah dilakukan pihak sekolah untuk menekan pelanggaran yang dilakukan siswa. Namun hal itu hanya berlangsung sebentar dan tidak memberikan efek jera bagi siswa. Usaha yang dilakukan berupa memberi sanksi tampak kurang efektif, informasi yang diberikan masih kurang jelas dan tidak efektif, menegur siswa masih kurang efektif.

Kedisiplinan peserta didik tampak tidak dapat diabaikan karena akan membawa dampak yang merugikan terhadap prestasi belajar maupun sikap mental para peserta didik, ketidakdisiplinan akan mengganggu pembelajaran sehingga berpengaruh pada prestasi belajar peserta didik. 
Oleh karena itu, dibutuhkan penanganan yang efektif, salah satunya adalah melalui layanan bimbingan dan konseling di sekolah yang akan membantu siswa dalam mencapai perkembangan yang optimal. Salah satu layanan bimbingan dan konseling yang dapat diterapkan dalam menigkatkan kedisiplinan siswa adalah melalui layanan bimbingan kelompok.

Layanan bimbingan kelompok adalah salah satu cara memberikan bantuan kepada individu melalui kegiatan kelompok yang didalamnya terdapat aktivitas dan dinamika kelompok yang harus diwujudkan untuk membahas topik-topik umum yang berguna bagi pengembangan atau pemecahan masalah individu (siswa) yang menjadi peserta layanan tersebut. Masalah yang menjadi topik pembicaraan dalam layanan bimbingan kelompok, dibahas melalui suasana dinamika kelompok secara intens dan konstruktif, diikuti oleh semua anggota kelompok di bawah bimbingan pemimpin kelompok. Dalam kegiatan layanan bimbingan kelompok dapat terjadi saling tukar pengalaman di antara para anggota yang dapat berpengaruh terhadap perubahan tingkah laku individu (Tohirin, 2015).

Dalam pelaksanaanya, layananan bimbingan kelompok memiliki beberapa kelebihan yaitu: 1) bimbingan kelompok lebih bersifat efektif dan efisien, 2) bimbingan kelompok dapat memanfaatkan pengaruh-pengaruh seseorang atau beberapa orang individu terhadap anggota lainya, 3) dalam bimbingan kelompok dapat terjadi saling tukar pengalaman di antara para anggotanya yang dapat berpengaruh terhadap perubahan tingkah laku individu, 4) bimbingan kelompok dapat merupakan awal dari konseling individual sehingga bimbingan kelompok dapat dimanfaatkan untuk memersiapkan individu yang akan mendapat layanan konseling, 5) dalam bimbingan kelompok terdapat kesempatan untuk menyegarkan watak/ pikiran. Bahwa melalui layanan bimbingan kelompok diharapakan dapat meningkatkan kesadaran tentang kedisiplinan siswa.

Berdasarkan latar belakang di atas, maka penulis tertarik untuk melaksanakan sebuah penelitian dengan judul "Pengaruh Layanan Bimbingan Kelompok terhadap Peningkatan kedisiplinan Siswa SMP Kesehatan Mandonga Kendari". Tujuan dari penelitian ini adalah untuk mengetahui pengaruh layanan bimbingan kelompok terhadap peningkatan kedisisiplinan siswa.
Kedisiplinan berasal dari kata disiplin. Istilah disiplin berasal dari bahasa Latin "disciplina" yang menunjukkan kepada kegiatan belajar dan mengajar. Istilah tersebut sangat dekat dengan istilah dalam bahasa Inggris "disciple" yang berarti mengikuti orang untuk belajar di bawah pengawasan seorang pemimpin. Dalam kegiatan belajar tersebut bawahan dilatih untuk patuh dan taat pada peraturan-peraturan yang dibuat oleh pemimpin. Sujiono dan Nurani (2005: 28) mengemukakan disiplin adalah tata tertib atau peraturan yang harus dilakukan dalam kehidupan sehari-hari untuk melatih dan watak anggota yang ada dalam lembaga pendidikan, sekolah militer atau organisasi kemasyarakatan. Disiplin yang dilakukan secara terus menerus akan menyebabkan siswa sekolah, akan menjadikan disiplin sebagai kebiasaan yang dapat diteladani.

Atheva (2007: 55) mengemukakan disiplin adalah sikap atau tingkah laku siswa yang taat peraturan yang ada di sekolah dalam menjalankan kewajibannya dengan penuh kesadaran. Disiplin sangat penting bagi setiap siswa, dan membuat siswa memiliki kecakapan mengenai cara belajar yang baik, juga merupkan suatu proses ke arah pembentukan yang baik. Selanjutnya, Tu'u (2004) mengemukakan bahwa disiplin sebagai upaya mengikuti dan menaati peraturan, nilai dan hukum yang berlaku, serta pengikutan dan ketaatan tersebut terutama muncul karena adanya kesadaran diri bahwa hal itu berguna bagi kebaikan dan keberhasilan dirinya.

Dari beberapa pendapat di atas, dapat dipahami bahwa disiplin adalah suatu sikap mengikuti dan menaati semua peraturan dengan tertib dan teratur serta dilaksanakan dengan penuh kesadaran dan bertanggung jawab.

\section{Jenis-jenis disiplin}

Asmani (2010: 94-95) mengemukakan jenisjenis disiplin siswa yaitu sebagai berikut.

1. Disiplin waktu, adalah mematuhi atau menaati waktu yang telah ditetapkan sekolah, menyelesaikan pekerjaan tepat waktu dan tidak menunda-nunda waktu untuk melakukan tugas atau kewajiban sebagai siswa, sehingga hidup kita menjadi efektif dan efisien.

2. Disiplin menegakkan aturan, disiplin peserta didik dapat dipupuk dengan memberikan tata tertib yang mengatur dalam lingkungan sekolah. Tata tertib disertai pengawasan akan membuat terlaksananya peraturan dan memberikan pengertian pada setiap 
pelanggaran, yang membuat timbulnya rasa keteraturan dan disiplin diri. Adapun tata tertib sekolah yang harus dipatuhi oleh peserta didik, peserta didik wajib berpakaian sesuai dengan ketentuan yang ditentukan sekolah, peserta didik wajib memelihara dan menjaga ketertiban serta menjunjung nama baik sekolah, selama jam sekolah berlangsung, peserta didik dilarang meninggalkan sekolah tanpa izin, peserta didik yang tidak dapat mengikuti pelajaran harus dengan menunjukkan keterangan yang sah dan peserta didik dilarang membawa segala sesuatu yang dapat menggangu kegiatan belajar mengajar.

3. Disiplin sikap, sikap mental yang tercermin dalam perbuatan tingkah laku perorangan atau siswa berupa kepatuhan atau ketaatan terhadap peraturan, ketentuan, etika, norma dan kaidah yang berlaku.

Berbeda dengan Asmani, Hurlock (2008: 93) terlebih dahulu membagi jenis disiplin orang tua yaitu sebagai berikut:

1. Disiplin otoriter, dalam disiplin yang bersifat otoriter, orang tua dan pengasuh yang lain menetapkan peraturan dan memberitahukan anak bahwa ia harus mematuhi peraturanperaturan tersebut. Tidak ada usaha untuk menjelaskan pada anak mengapa ia harus patuh dan tidak diberi kesempatan untuk mengemukakan pendapat tentang adil tidaknya peraturan-peraturan tersebut.

2. Disiplin yang lemah, filsafat yang mendasari teknik disiplin ini adalah melalui akibat dari perbuatannya sendiri, anak akan belajar bagaimana berperilaku secara sosial. Dengan demikian, tidak diajarkan peraturan-peraturan, ia tidak dihukum karena melakukan pelanggaran dan tidak diberi hadiah bagi anak yang berperilaku baik.

3. Disiplin demokratis, disiplin ini menekankan pada anak untuk mengetahui mengapa peraturan yang dibuat dan memeroleh kesempatan mengemukakan pendapatnya sendiri bila ia menganggap peraturan itu tidak adil. Terdapat pemberian hukuman bagi anak yang melanggar dan pemberian hadiah bagi yang berperilaku baik.

Berdasarkan uraian di atas dapat disimpulkan bahwa jenis-jenis disiplin yang dapat dilakukan oleh siswa terdiri dari disiplin waktu, disiplin menegakkan aturan, disiplin sikap, disiplin otoriter, disiplin yang lemah dan disiplin demokratis.

\section{Ciri-ciri disiplin}

Menurut Atheva (dalam Elly, 2016: 47) orang yang disiplin memiliki ciri-ciri sebagai berikut:

1. Selalu menaati peraturan atau tata tertib yang ada.

2. Selalu melaksanakan tugas dan kewajiban yang diterimanya dengan tepat waktu.

3. Kehidupannya tertib dan teratur.

4. Tidak mengulur-ulur waku dan menunda pekerjaan.

Faktor-faktor yang memengaruhi disiplin

Tu'u (2004: 49-50) menyebutkan bahwa, ada beberapa faktor yang berpengaruh pada pembentukan disiplin individu yaitu sebagai berikut:

1. Teladan. Perbuatan dan tindakan kerap kali besar pengarunya dibandingkan dengan katakata, jadi keteladanan sangat penting bagi perilaku disiplin siswa. Dalam disiplin di sekolah, semua insan yang ada di dalamnya mengembangkan kepengikutan dan ketaatan yang lahir dari kesadaran dirinya sehingga terbentuk jiwa displin yang dapat menjadi contoh.

2. Lingkungan berdisiplin. Seseorang dapat juga dipengaruhi oleh lingkungan, bila berada di lingkungan berdisiplin, seseorang dapat terbawa oleh lingkungan tersebut. Peraturan-peraturan yang ditaati dan dipatuhi adalah yang berlaku dalam lingkungan tersebut, dengan tujuan menciptakan lingkungan kondusif bagi kegiatan dan proses pendidikan.

3. Latihan disiplin. Disiplin dapat dicapai dan dibentuk melalui proses latihan dan kebiasaan dalam mengikuti, menaati dan mematuhi peraturan yang berlaku.

Unaradjan (2003: 27-32) menyebutkan terbentuknya disiplin diri sebagai tingkah laku yang berpola dan teratur dipengaruhi oleh dua faktor berikut:

1. Faktor-faktor ekstern, yang dimaksud dalam hal ini adalah unsur-unsur yang berasal dari luar pribadi yang dibina. Faktor-faktor tersebut yaitu:

a. Keadaan keluarga. Keluarga sebagai tempat pertama dan utama dalam pembinaan pribadi 
dan merupakan salah satu faktor yang sangat penting. Keluarga memengaruhi dan menentukan perkembangan pribadi seseorang di kemudian hari. Keluarga dapat menjadi faktor pendukung atau penghambat usaha pembinaan perilaku disiplin.

b. Keadaan lingkungan sekolah. Pembinaan dan pendidikan disiplin di sekolah ditentukan oleh keadaan sekolah tersebut. Keadaan sekolah dalam hal ini adalah ada tidaknya sarana-sarana yang diperlukan bagi kelancaran proses belajar mengajar di tempat tersebut dan termasuk dalam sarana tersebut antara lain seperti gedung sekolah dengan segala perlengkapannya, pendidikan atau pengajaran serta sarana-sarana pendidikan lainnya.

c. Keadaan lingkungan masyarakat. Masyarakat sebagai suatu lingkungan yang lebih luas dari pada keluarga dan sekolah, yang juga turut menentukan berhasil tidaknya pembinaan dan pendidikan disiplin diri. Suatu keadaan tertentu dalam masyarakat dapat menghambat atau memerlancar terbentuknya kualitas hidup tersebut.

2. Faktor-faktor intern, yaitu unsur-unsur yang berasal dari dalam diri individu. Dalam hal ini, keadaan fisik dan psikis pribadi tersebut memengaruhi unsur pembentukan disiplin dalam diri individu.

a. Keadaan fisik. Individu yang sehat secara fisik atau biologis akan dapat menunaikan tugas-tugas yang ada dengan baik. Dengan penuh vitalis dan ketenangan, ia mampu mengatur waktu untuk mengikuti berbagai cara atau aktifitas secara seimbang dan lancar. Dalam situasi semacam ini, kesadaran pribadi yang bersangkutan tidak akan terganggu sehingga ia akan menaati norma-norma atau peraturan yang ada secara bertanggung jawab.

b. Keadaan psikis. Keadaan fisik seseorang memunyai kaitan erat dengan keadaan batin atau psikis seseorang tersebut, karena hanya orang-orang yang normal secara psikis atau mental yang dapat menghayati norma-norma yang ada dalam masyarakat dan keluarga. Di samping itu, terdapat beberapa sifat atau sikap yang menjadi penghalang usaha pembentukan perilaku disiplin dalam diri individu. Seperti sifat perfeksionisme, perasaan sedih, perasaan rendah diri atau inferior.

Sukardi (2000: 48) mengemukakan layanan bimbingan kelompok yaitu layanan bimbingan yang mungkin peserta didik secara bersama-sama memeroleh berbagai bahan dari nara sumber tertentu (terutama dari pembimbing/ konselor) yang berguna untuk menunjang kehidupannya sehari-hari baik individu maupun sebagai pelajar, anggota keluarga dan masyarakat serta untuk pertimbangan dalam pengambilan keputusan. Selanjutnya, Tohirin (2015: 164) menjelaskan layanan bimbingan kelompok adalah salah satu cara memberikan bantuan kepada individu melalui kegiatan kelompok yang di dalamnya terdapat aktivitas dan dinamika kelompok yang harus diwujudkan untuk membahas topik-topik umum yang berguna bagi pengembangan atau pemecahan masalah individu (siswa) yang menjadi peserta layanan tersebut. Masalah yang menjadi topik pembicaraan dalam layanan bimbingan kelompok, dibahas melalui suasana dinamika kelompok secara intens dan konstruktif, diikuti oleh semua anggota kelompok dibawah bimbingan pemimpin kelompok (konselor).

Nurihsan (2007: 23) mengemukakan bahwa layanan bimbingan kelompok merupakan bantuan terhadap individu yang dilaksanakan dalam situasi kelompok. Bimbingan kelompok dapat berupa penyampaian informasi ataupun aktivitas kelompok membahas masalah-masalah pendidikan, pekerjaan, pribadi dan sosial. Dinamika kelompok erat kaitannya dengan kegiatan bimbingan. Dinamika kelompok adalah kekuatan-kekuatan yang berinteraksi dalam kelompok pada waktu kelompok melakukan kegiatan-kegiatan untuk mencapai tujuannya. Adapun kegiatan layanan bimbingan kelompok yang dapat menumbuh kembangkan dinamika kelompok yaitu pemberian informasi, karena layanan informasi yang diberikan dalam bimbingan kelompok dimaksudkan untuk memerbaiki dan mengembangkan pemahaman diri dan orang lain, sedangkan perubahan sikap merupakan tujuan yang tidak langsung. Sehingga adanya layanan informasi didalam kegiatan bimbingan kelompok mengenai perilaku disiplin.

Dari beberapa pendapat tersebut, dapat disimpulkan bahwa bimbingan kelompok merupakan sebuah layanan yang berupaya memberikan bantuan kepada siswa dengan memanfaatkan dinamika kelompok agar mampu 
menyusun rencana dan keputusan yang tepat dalam suasana kelompok, sehingga nantinya dapat berguna untuk meunjang aktifitas dalan kehidupannya.

Tujuan layanan bimbingan kelompok

Prayitno dan Amti (2015: 114), menjelaskan tujuan layanan bimbingan kelompok sebagai berikut:

1. Tujuan umum. Tujuan umum kegiatan layanan bimbingan kelompok adalah berkembangnya kemampuan sosialisasi siswa, khususnya kemampuan komunikasi peserta layanan. Dalam kaitan ini, sering menjadi kenyataan bahwa kemampuan bersosialisasi/ berkomunikasi seseorang sering terganggu perasaan, pikiran. Persepsi wawasan dan sikap yang tidak objektif, sempit dan terkungkung serta tidak efektif.

2. Tujuan khusus. Secara khusus, layanan bimbingan kelompok bertujuan untuk membahas topik-topik tertentu yang mengandung permasalahan aktual (hangat) dan menjadi perhatian peserta.

\section{Dinamika kelompok}

Winkel dan Hastuti (2006: 547) mengemukakan bahwa dinamika kelompok adalah pengetahuan yang menggambarkan berbagai kekuatan yang menunjukkan perilaku anggota dan perilaku kelompok yang menyebabkan terjadinya gerak perubahan dalam kelompok untuk mencapai tujuan bersama yang telah ditetapkan. Dinamika kelompok merupakan sinergi dari semua faktor yang ada dalam suatu kelompok, artinya merupakan pengarahan secara serentak semua faktor yang dapat digerakkan dalam kelompok itu. Selanjutnya winkel dan Hastuti (2006: 547) menjelaskan dinamika kelompok mengarahkan anggota kelompok untuk melakukan hubungan interpersonal satu sama lain. Dari hubungan interpersonal ini merupakan wahana bagi para anggota untuk saling berbagi pengetahuan, pengalaman dan bahkan perasaan satu sama lain sehingga memungkinkan terjadinya proses belajar di dalam kelompok yang kohesif.

Prayitno (2002: 32) menguraikan peranan yang hendaknya dimainkan oleh anggota kelompok agar dinamika kelompok itu benar-benar seperti yang diharapkan yakni:

1. Membantu terbinanya suasana keakraban dalam hubungan antar angota kelompok.
2. Mencurahkan segenap perasaan dalam melibatkan diri dalam kegiatan kelompok.

3. Berusaha agar yang dilaksanakannya itu membantu tercapainya tujuan bersama.

4. Membantu tersusunnya aturan kelompok dan berusaha mematuhinya dengan baik.

5. Benar-benar berusaha untuk secara aktif ikut serta dalam seluruh kegiatan kelompok.

6. Mampu berkomunikasi secara terbuka.

7. Berusaha membantu anggota lain.

8. Memberi kesempatan kepada anggota lain untuk juga menjalankan perannya.

9. Menyadari pentingnya kelompok itu.

Dari penjelasan di atas dapat disimpulkan bahwa bimbingan kelompok memanfaatkan dinamika kelompok sebagai wahana dalam membimbing anggota kelompok untuk mencapai tujuan. Dinamika kelompok adalah kekuatan di dalam kelompok yang menetukan perilaku kelompok dan anggotanya agar tercapai tujuan kelompok, dinamika kelompok mengarahkan anggota kelompok menjalin hubungan interpersonal sehingga proses bimbingan kelompok diharapkan dapat berjalan dengan lancar sesuai dengan prosedur dan sistematika yang baik.

\section{Tahap layanan bimbingan kelompok}

Nurihsan (2005: 18) mengemukakan tahap pelaksanaan layanan bimbingan kelompok sebagai berikut:

1. Langkah awal. Langkah awal ini dimulai dengan penjelasan tentang adanya layanan bimbingan kelompok bagi para siswa mulai dari pengertian, tujuan dan kegunaan bimbingan kelompok. Setelah penjelasan ini, langkah selanjutnya menghasilkan kelompok yang langsung merencanakan waktu dan tempat menyelenggarakan kegiatan bimbingan kelompok.

2. Perencanaan kegiatan. Perencanaan kegiatan bimbingan kelompok meliputi penetapan materi layanan, tujuan yang ingin dicapai, sasaran kegiatan, bahan atau sumber bahan untuk bimbingan kelompok, rencana penilaian serta waktu dan tempat.

3. Pelaksanaan kegiatan. Kegiatan yang telah direncanakan itu selanjutnya dilaksanakan melalui kegiatan sebagai berikut:

a. Persiapan menyeluruh yang meliputi persiapan fisik tempat dan kelengkapannya: persiapan bahan, persiapan keterampilan dan persiapan administrasi. 
b. Pelaksanaan tahap-tahap kegiatan

1) Tahap pertama: Pembentukan

Temanya pengenalan, pelibatan, dan pemasukan diri. Meliputi kegiatan: (a) mengungkapkan pengertian dan tujuan bimbingan kelompok (b) menjelaskan cara-cara dan asas-asas bimbingan kelompok (c) saling memerkenalkan dan mengungkapkan diri (d) teknik khusus (e) permainan penghangatan/ pengakraban.

2) Tahap kedua: Peralihan

Meliputi kegiatan: (a) menjelaskan kegiatan yang akan ditempuh pada tahap berikutnya (b) menawarkan atau mengamati apakah para anggota sudah siap menjalani kegiatan pada tahap selanjutnya (c) membahas suasana yang terjadi (d) meningkatkan kemampuan keikutsertaan anggota (e) kalau perlu kembali ke beberapa aspek tahap pertama atau tahap pembentukan.

3) Tahap ketiga: kegiatan

Meliputi kegiatan: (a) pemimpin kelompok mengemukakan suatu masalah atau topik (b) tanya jawab antara anggota dan pemimpin kelompok tentang hal-hal yang belum jelas yang menyangkut masalah atau topik yang dikemukakan pemimpin kelompok (c) anggota membahas masalah atau topik tersebut secara mendalam dan tuntas (d) kegiatan selingan.

4. Evaluasi kegiatan. Penilaian kegiatan layanan bimbingan kelompok difokuskan pada perkembangan pribadi siswa dan hal-hal yang dirasakan mereka berguna. Isi kesan-kesan yang diungkapkan oleh para peserta merupakan isi penilaian yang sebenarnya. Penilaian terhadap bimbingan kelompok dapat dilakukan secara tertulis baik secara essai, daftar cek maupun daftar isian sederhana.

5. Analisis tindak lanjut. Hasil penilaian kegiatan bimbingan kelompok perlu dianalisis untuk mengetahui lebih lanjut seluk beluk kemajuan para peserta dan seluk beluk penyelenggaraan bimbingan kelompok. Usaha tindak lanjut mengikuti arah dan hasil analisis tersebut. Tindak lanjut itu dapat dilaksanakan melalui bimbingan kelompok selanjutnya atau kegiatan sudah dianggap memadai dan selesai sehingga oleh karenanya upaya tindak lanjut secara tersendiri dianggap tidak diperlukan.

\section{Metode Penelitian}

Penelitian ini dilaksanakan di SMP Kesehatan Mandonga Kendari pada tahun akademik 2017/ 2018. Penelitian ini merupakan penelitian kuantitatif dengan metode praeksperimen. Praeksperimen merupakan susunan desain penelitian yang dilakukan dengan jalan memberikan perlakuan kepada subjek tanpa adanya kelompok kontrol (Latipun, 2002: 68). Olehnya itu bentuk desain pra eksperimen yang digunakan adalah one group pretest and posttest design.

Gall, Gall \& Borg (dalam Setyosari 2013: 182) menjelaskan desain penelitian one group pretest-posttest meliputi tiga langkah, yaitu: 1) pelaksanaan pre-test untuk mengukur variabel terikat, 2) pelaksanaan perlakuan atau eksperimen, dan 3) pelaksanaan post-test untuk mengukur hasil atau dampak terhadap variabel terikat. Dengan demikian, dampak perlakuan ditentukan dengan cara membandingkan skor hasil pra-tes dan paska tes.

Subjek dalam penelitian ini adalah siswa yang berjumlah 8 orang dengan rincian 6 orang subjek memiliki skor kedisiplinan rendah, 1 orang memiliki skor kedisiplinan tinggi dan 1 orang subjek memiliki skor kedisiplinan. Teknik pengambilan subjek dengan menggunakan teknik purposive sampling.

Dalam penelitian ini, peneliti menggunakan angket sebagai teknik pengumpulan data yang digunakan untuk mengaji pengaruh bimbingan kelompok dalam meningkatkan kedisiplinan siswa. Teknik analisis data menggunakan analisis deskriptif persentase untuk mengetahui gambaran kedisiplinan siswa dan statistik inferensial digunakan untuk menguji hipotesis penelitian.

\section{Hasil Penelitian dan Pembahasan Hasil Penelitian}

Analisis deskriptif

Gambaran kedisiplinan siswa SMP

Kesehatan Mandonga Kendari sebelum diberikan perlakuan (pre test) dapat diketahui berdasarkan hasil pengisisan angket kedisiplinan yang diberikan pada 8 orang siswa. Skor pre test yang diperoleh dari subjek penelitian dikonversikan dalam kategori penilaian dengan menggunakan analisis deskriptif persentase, sebagaimana yang tertera pada tabel berikut: 
Tabel 1

Skor Pre Test Kedisiplinan Siswa

\begin{tabular}{|c|c|c|c|c|}
\hline No & Nama & Skor & $\%$ & Kriteria \\
\hline 1 & KR & 112 & $53.84 \%$ & Rendah \\
\hline 2 & AA & 122 & $58.65 \%$ & Rendah \\
\hline 3 & $\mathrm{~F}$ & 123 & $59.13 \%$ & Rendah \\
\hline 4 & NNF & 127 & $60.57 \%$ & Rendah \\
\hline 5 & MI & 117 & $56.25 \%$ & Rendah \\
\hline 6 & AMJ & 121 & $58.17 \%$ & Rendah \\
\hline 7 & DSR & 150 & $71.63 \%$ & Tinggi \\
\hline 8 & YAA & 168 & $80.76 \%$ & Sangat Tinggi \\
\hline \multicolumn{2}{|c|}{ Jumlah } & 1040 & $499 \%$ & \multirow{2}{*}{ Rendah } \\
\hline \multicolumn{2}{|c|}{ Rata-rata } & 130 & $62.38 \%$ & \\
\hline
\end{tabular}

Berdasarkan tabel di atas, kedisiplinan siswa sebelum diberikan perlakuan (pre test) termasuk dalam kategori rendah. Hal ini dapat dilihat dari rata-rata persentase kedisiplinan siswa mencapai $62,38 \%$ dari 8 orang subjek penelitian.

Selanjutnya, gambaran kemandirian belajar siswa setelah diberikan perlakuan berupa layanan bimbingan kelompok dapat diketahui berdasarkan hasil analisis angket kedisiplinan siswa, sebagaimana yang tertera pada tabel berikut ini:

Tabel 2

Skor Post Test Kedisiplinan Siswa

\begin{tabular}{|c|c|c|c|c|}
\hline No. & Nama & Skor & $\%$ & Kriteria \\
\hline 1 & KR & 161 & $77,40 \%$ & Tinggi \\
\hline 2 & AA & 164 & $78,85 \%$ & Tinggi \\
\hline 3 & $\mathrm{~F}$ & 157 & $75,49 \%$ & Tinggi \\
\hline 4 & NNF & 161 & $77,40 \%$ & Tinggi \\
\hline 5 & MI & 160 & $76,92 \%$ & Tinggi \\
\hline 6 & AMJ & 156 & $75,00 \%$ & Tinggi \\
\hline 7 & DSR & 173 & $83,17 \%$ & Sangat Tinggi \\
\hline 8 & YAA & 180 & $86,53 \%$ & Sangat Tinggi \\
\hline \multicolumn{2}{|c|}{ Jumlah } & 1312 & 630,76 & \multirow{2}{*}{ Rendah } \\
\hline \multicolumn{2}{|c|}{ Rata-Rata } & 164 & $78,85 \%$ & \\
\hline
\end{tabular}

Berdasarkan tabel di atas, kedisiplinan siswa setelah diberikan perlakuan (post test) mengalami perubahan kategori tinggi menjadi tinggi. Hal ini dapat dilihat dari rata-rata persentase yang diperoleh yakni sekitar $78,85 \%$ dari 8 orang subjek penelitian.

Perbandingan skor pre test dan post test kedisiplinan siswa

Berdasarkan hasil analisis data, maka dapat diperoleh gambaran kedisiplinan siswa kelas VIII SMP Kesehatan Mandonga Kendari sebelum dan sesudah diberikan perlakuan. Adapun hasil analisis data tersebut dapat dilihat pada tabel berikut ini:
Tabel 3

Perbandingan Skor Pre Test dan Post Test Kedisiplinan Siswa

\begin{tabular}{|c|c|c|c|c|c|c|}
\hline \multirow{2}{*}{ E. } & \multirow{2}{*}{ 5y } & \multicolumn{2}{|c|}{56} & \multicolumn{2}{|c|}{ Ft. i } & \multirow{2}{*}{ 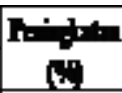 } \\
\hline & & hIJ & Faldes & hInI & FyId- & \\
\hline 1 & KR & 8B: & $n_{1}$ & P.-11 & fai & $\mathbf{B S}$ \\
\hline 2 & M. & 5 & 75 & P.!1 & Thi & 212 \\
\hline 3 & $\mathbf{F}$ & 913 & $5 \theta$ & P.!1 & In-i & 163 \\
\hline 4 & Eis & 돠 & $n_{0}$ & P.!1 & F-i & 153 \\
\hline 5 & 1 & siv & $\mathrm{xth}$ & P.!1 & fai & 20 \\
\hline 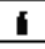 & IT & 요군 & 5n & P.1. & F.i. & $16 B$ \\
\hline 7 & IE: & 78 & 317 & fin.i & I.: & 115 \\
\hline 1 & Y.M. & 매 & 58 & efrif & 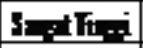 & 57 \\
\hline 1 & Hr & 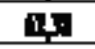 & 75 & 1.1. & I... & lists \\
\hline
\end{tabular}

Dari tabel di atas diketahui bahwa sebelum diberi perlakuan (pre test) tingkat kedisiplinan siswa masuk dalam kategori rendah dengan skor persentase rata-rata $62,38 \%$. Sedangkan, setelah diberikan perlakuan (post test) tingkat kedisiplinan siswa berada kategori tinggi dengan skor persentase rata-rata $78,85 \%$. Hal tersebut menunjukkan bahwa tingkat kedisiplinan siswa di SMP Kesehatan Mandonga Kendari mengalami peningkatan sebesar $16,47 \%$ setelah diberikan perlakuan berupa bimbingan kelompok.

Analisis statistik inferensial

Analisis data untuk mengetahui layanan bimbingan kelompok berpengaruh dalam meningkatkan kedisiplinan siswa kelas VIII SMP Kesehatan Mandonga Kendari dilakukan analisis non parametrik dengan uji wilcoxon signed rank. Hasil perhitungan uji Wilcoxon signed rank. Dengan menggunakan SPSS 16.00.

Berdasarkan analisis statistik inferensial dengan menggunakan uji wilcoxon signed rank pada taraf signifikan $\alpha=0,05$ diperoleh $P_{\text {value }}=$ 0,027 oleh karena $P_{\text {value }}<\alpha \quad(0,027<0,05)$ maka $\mathrm{H}_{\mathrm{o}}$ ditolak. Hal ini berarti layanan bimbingan kelompok berpengaruh terhadap peningkatan kedisiplinan siswa.

\section{Pembahasan}

Layanan bimbingan kelompok dapat meningkatkan kedisiplinan siswa yang rendah, sebagaimana yang diperoleh sebagai hasil dalam penelitian ini bahwa tingkat kedisiplinan siswa kelas VIII SMP Kesehatan Mandonga kendari mengalami peningkatan kedisiplinan siswa sebesar $16,47 \%$. Hasil penelitian ini memerkuat oleh penelitian terdahulu yang dilakukan oleh Widosari (2014) dengan judul "Upaya meningkatkan 
kedisiplinan melalui layanan bimbingan kelompok dengan teknik behavior pada siswa MTs Fatahillah Rejosari Semarang". Hasil penelitian ini juga memertegas hasil penelitian yang dilakukan oleh Sari (2018) dengan judul "Upaya Meningkatkan Perilaku Disiplin Siswa Melalui Layanan Bimbingan Kelompok" yang menunjukkan bahwa layanan bimbingan kelompok terbukti dapat meningkatkan disiplin dengan tingkat kenaikan yang signifikan.

Bimbingan kelompok merupakan salah satu metode yang dapat digunakan untuk meningkatkan kedisiplinan siswa. Hal ini dikarenakan bimbingan kelompok adalah untuk membantu siswa mencegah atau menghindarkan diri dari berbagai permasalahan yang dapat menghambat perkembangan dirinya melalui dinamika kelompok yang muncul selama proses bimbingan kelompok.

Sukardi (2002: 48) menyatakan bahwa layanan bimbingan kelompok merupakan layanan bimbingan yang memungkinkan sejumlah peserta didik secara bersama-sama memeroleh berbagai bahan dari narasumber tertentu (terutama dari pembimbing/ konselor) yang berguna untuk menunjang kehidupannya sehari-hari baik individu maupun sebagai pelajar, anggota keluarga dan masyarakat serta untuk pertimbangan dalam pengambilan keputusan.

Setelah diberikan perlakuan (treatment) layanan bimbingan kelompok, siswa selanjutnya mengisi post test yang diberikan oleh peneliti. Tujuan dari pemberian post test adalah untuk mengetahui tingkatkan keberhasilan pelaksanaan perlakuan dan peningkatan kedisiplin an siswa yang rendah. Berdasarkan hasil rata-rata kedisiplinan siswa setelah diberikan layanan bimbingan kelompok (post test) termasuk dalam kategori tinggi yaitu sebesar 78,85\%. Hal ini sejalan dengan pendapat Tu'u (2004) yang mengemukakan bahwa disiplin sebagai upaya mengikuti dan menaati peraturan, nilai dan hukuman yang berlaku serta pengikutan dan kataatan tersebut terutama muncul karena adanya kesadaran diri bahwa hal itu berguna bagi kebaikan dan keberhasilan dirinya.

Peningkatan kedisiplinan siswa nampak pada masing-masing indikator kedisiplinan. Berdasarkan hasil analisis, rerata indikator kedisiplinan siswa sebelum diberikan perlakuan adalah $62,72 \%$ dan masuk dalam kategori rendah. Setelah diberikan perlakuan, rata-rata indikator kedisplinan siswa mengalami peningkatan $16,16 \%$ sehingga menjadi $78,89 \%$ dan masuk dalam kategori tinggi. Indikator yang mengalami peningkatan tertinggi adalah indikator keempat yaitu tidak mengulur waktu dan menunda pekerjan dengan peningkatan $22,14 \%$. Terjadi peningkatan dikarenakan dalam pemberian layanan bimbingan kelompok menggunakan teknik diskusi dan tanya jawab dan didukung oleh materi yang tepat serta semua anggota kelompok antusias mendengarkan materi, mau memberikan pertayaan dan berani menjawab pertanyaan yang diajukan oleh konseli.

Selanjutnya, indikator yang mengalami peningkatan terendah adalah indikator pertama yaitu taat peraturan atau tata tertib dengan peningkatan $4,54 \%$. Hal ini dapat dikarenakan pada waktu pengisian angket siswa yang berperilaku tidak disiplin cenderung ingin terlihat baik atau mendapat pujian dari teman-temannya untuk menutupi perilaku yang sebenarnya (Dembo, 2000).

Dalam meningkatkan kedisiplinan siswa, guru bimbingan dan konseling dapat memberikan layanan bimbingan kelompok. Pada pelaksanaan layanan bimbingan kelompok, dinamika kelompok memiliki peranan penting dalam mengembangkan kedisiplinan siswa, dimana anggota kelompok saling berinteraksi membahas topik yang diberikan oleh pemimpin kelompok, dilanjutkan dengan diskusi dan tanya jawab untuk lebih memerdalam materi. Sehingga siswa mengetahui tujuan diadakannya layanan bimbingan kelompok, yakni sebagai upaya untuk meningkatkan kedisiplinan siswa serta anggota kelompok membuat komitmen bahwa apa yang telah dibahas selama pemberian layanan bimbingan kelompok dapat diterapkan dalam kehidupan sehari-hari.

Menurut Prayitno (2004: 3), layanan bimbingan kelompok dapat digunakan untuk mengubah dan mengembangkan sikap dan perilaku yang tidak efektif menjadi lebih efektif. Melalui layanan bimbingan kelompok siswa dilatih untuk mampu melakukan kegiatan secara berkelompok untuk mencapai tujuan bersama. Bimbingan kelompok sebagai media dalam upaya membimbing individu yang memerlukan bantuan, dalam hal ini yaitu individu yang memerlukan bantuan untuk mengembangkan karakter disiplin dengan memanfaatkan dinamika kelompok.

\section{Kesimpulan dan saran \\ Kesimpulan}

Berdasarkan hasil analisis terhadap data penelitian, dapat ditarik kesimpulan bahwa layanan bimbingan kelompok berpengaruh terhadap 
peningkatan kedisiplinan siswa SMP Kesehatan Mandonga Kendari.

\section{Saran}

1. Bagi sekolah. Sekolah mestinya memberi kebijakan untuk mendukung guru bimbingan dan konseling dalam mengaplikasikan layanan bimbingan dan konseling dengan menyediakan ruangang khusus bagi guru BK.

2. Bagi guru BK. Guru BK perlu mengadakan program layanan bimbingan kelompok khusus dalam mengatasi masalah kedisiplinan siswa.

3. Bagi siswa. Semoga dapat mengikuti setiap pemberian layanan bimbingan dan konseling yang diterapkan di sekolah khususnya layanan bimbingan kelompok, serta serius menyikapi dengan baik apa yang diberikan oleh guru BK.

4. Bagi peneliti selanjutnya. Penelitian ini memberikan gambaran bahwa layanan bimbingan kelompok memiliki pengaruh dalam meningkatkan kedisiplinan siswa, sehingga penulis lebih mendalami masalah kedisiplinan sangat dibutuhkan untuk penelitian lanjutan. Peneliti selanjutnya dapat mengembangkan penelitian ini dengan menambahkan teknik atau metode dalam pemberian layanan misalnya menggunakan metode observasi atau dicek kembali melalui wawancara guru BK.

\section{Daftar Pustaka}

Arikunto, Suharsimi. (1997). Prosedur Penelitian Suatu Pendekatan Praktek. Jakarta: PT.Rineka Cipta.

Atheva, Abi. (2007). Perilaku Baik Sehari-hari. Semarang: CV Aneka Ilmu.

Asmani, Jamal Ma'mur. (2010). Tips Menjadi Guru Inspiratif, Kreatif, dan Inovatif. Yogyakarta: Diva Press.

Dembo, H Myron. (2000). The Elementary School Journal Volume 100, Number 5 C. The University of Chicago.

Elly, Rosma. (2016). Hubungan Kedisiplinan Terhadap Hasil Belajar Siswa. Jurnal Universitas Syiah Kuala. Vol. 3 No.4.

Hurlock, Elizabeth B. (2008). Psikologi Perkembangan Suatu Sepanjang Rentang Kehidupan (Edisi 5). terjemahan
Istiwidayanti dan Soedjarwo. Jakarta: Erlangga.

Latipun. (2002). Psikologi Eksperimen. Malang: UMM Press.

Nurihsan, Achmad Juntika. (2007). Bimbingan dan Konseling Dalam Latar Belakang Kehidupan. Bandung: PT Refika Aditama.

Nurihsan, Achmad Juntika. (2005). Strategi Layanan Bimbingan Dan Konseling. Bandung: PT Refika Aditama.

Prayitno dan Erman Amti. (2015). Dasar-dasar Bimbingan dan Konseling. Jakarta: PT Rineka Cipta.

Prayitno. (1995). Layanan Bimbingan dan Konseling Kelompok (Dasar dan Profil) Jakarta: Ghalia Indonesia.

Rachman, Maman. (1999). Manajemen Kelas. Jakarta:Depdiknas, Proyek Pendidikan Guru SD.

Sujiono, Bambang \& Nurani Yuliana. (2005). Mencerdaskan Perilaku Anak Usia Dini. Jakarta: PT Elex Media Komputindo.

Sukardi, Dewa Ketut. (2000). Pengantar Pelaksanaan Program Bimbingan dan Konseling Di Sekolah. Jakarta: PT.Rineka Cipta.

Sari, Aqnaa Wasi. (2008). Upaya Meningkatkan Perilaku Disiplin Siswa Melalui Layanan Bimbingan Kelompok Kelas 8 Di SMPN 11 Semarang. Skripsi. Universitas Negeri Semarang.

Setyosari, Punaji. (2013). Metode Penelitian Pendidikan dan Pengembangan. Jakarta: Kencana.

Tu'u, Tulus. (2004). Peran Disiplin Pada Perilaku dan Prestasi Siswa. Jakarta: PT. Grasindo.

Tohirin. (2015). Bimbingan dan Konseling Di Sekolah Dan Madrasah (Berbasis Integrasi). Jakarta: PT. Raja Grafindo Persada. 
Unuradjan, Dolet (2003). Manajemen Disiplin. Jakarta: PT. Gramedia Widiasarana Indonesia.

Winkel \& Sri Hastuti. (2004). Bimbingan dan Konseling di Institusi Pendidikan. Yogyakarta: Media Abadi.

Widosari, Lilik. (2014). Upaya Meningkatkan Kedisiplinan Melalui Layanan Bimbingan Kelompok Dengan Teknik Behavior Pada Siswa. Jurnal Universitas Veteran Semarang Vol. 2 No. 1. 
Jurnal BENING Volume 4 Nomor 1 Januari 2020

98 | Risma, Waode Suarni, Alber Tigor Arifyanto 